\title{
A Review on Pharmacological Profile of Ethanamide and their Derivatives
}

\author{
${ }^{1}$ Rahul Chauhan ${ }^{*}{ }^{2}$ Pooja Saini, ${ }^{3}$ Richa Choudhary, ${ }^{4}$ Sonam Rani \\ ${ }^{1}$ MET Faculty of Pharmacy, Moradabad-244001 (U.P.), India. \\ 2 Faculty of Pharmacy, IFTM University, Lodhipur Rajput- 244102, Moradabad, India. \\ ${ }^{3}$ MIT College of Pharmacy, Moradabad-244001, India. \\ 4 Shri Satya Institute of Pharmacy, Lodhipur Rajput, Moradabad, U.P. 244102, India. \\ *Corresponding author's E-mail: DrxRahulchauhan623@gmail.com
}

Received: 09-08-2020; Revised: 25-09-2020; Accepted: 04-10-2020; Published on: 20-10-2020.

\begin{abstract}
Acetamide is a natural aggravate, this is the sensible amide get from acidic corrosive. The associated compound $\mathrm{N}, \mathrm{N}$ dimethylacetamide is extra commonly utilized, yet this isn't make ready from acetamide the Lewis corrosive belongings before acetamides whichever is worn as systematic substance yet in addition utilized in the of a blend. Acetamide was first made in the year 1986 by the principal created in France and has been accessible in Europe since 1986. The America considering, the helpful of African dozing ailment. Modafinil acknowledged beginning inside 1998. However, as a medication Acetamide is an oral and the equivalent can be in intravenous from sedate organization can be a suppository in butt-centric course or an inward breath course. Which is utilized in explicit cases. As 10-subbed subordinates. Through with so much regarded too have dissolving operator like natural mixes inflammable emollients with hygroscopic specialist. The most noticeable utilization of these subordinates is as luxurious Sess pain relieving action. Since it has defused a Paracetamol, the world's most generally Used medications which is one of the is a case of pain relieving operators. It is additionally answered to have at acetamide is liable for antimicrobial cancer prevention agent calming exercises. Practical gathering able. The natural assessment of the CNS operator action has been performed. Out of the biologic thought, it is built up such know about all the makes three combination seem dynamic focal sensory system delegate movement. The writing demonstrates that Acetamide show impacts like antimicrobial exercises, cancer prevention agent exercises, and calming exercises. CNS operator, and so forth. From result discussion exclusively, such the substitution at fragrant phenol have commended extent to yield likewise esteem. The warm cycloaddition or $\mathrm{N}$ alkanoylation vilsmeier Haack response steps included by buildup followed. This article gives different strategies to get ready more subordinates of Acetamide to investigate more exercises of acetamide.
\end{abstract}

Keywords: Acetamide, Organic compound, CNS Agent.

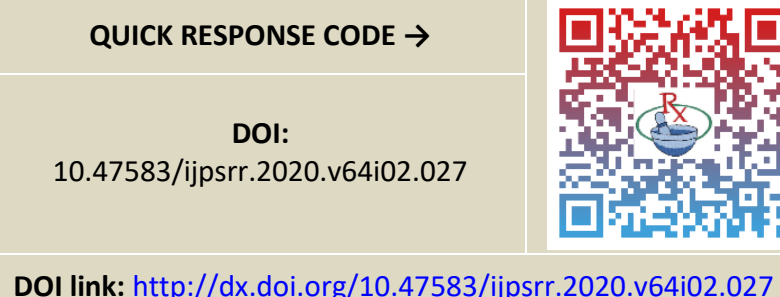

\section{INTRODUCTION}

$\mathrm{M}$ ixes with an acetamide linkage show assortment of utilizations Lewis corrosive property of acetamides makes their utilization as investigative reagents and in the planning by an imprint by edifices. At that point ethanamide bunch is manageable in antimicrobial ascorbic corrosive additionally COX-inhibitor (NSAID) activity. The usages of acetamides and analogs are along these lines using like adversary of malady agents extensively considered. The bioactive auxiliaries of acetamides are commonly obtained from regular things and moreover by fabricated procedures. The different substance and natural properties of these mixes are discovered significance in industry and furthermore in pharmaceutical arrangements. Maybe these are the explanations behind a developing enthusiasm for the investigation of the union, natural properties and structure movement connections of acetamides. These ties on the acetamides have made the current exploration which is including the amalgamation, portrayal and organic assessment of some new acetamides and active investigation of two acetamides, lidocaine and o-acetamidophenol. Acetamide buildup is found in numerous proteins and mammalian discharges like $\mathrm{N}$-acetylaspartyl glutamic corrosive and furthermore by manufactured techniques. Acetamide buildup is found in numerous proteins and mammalian emissions like $\mathrm{N}$-acetylaspartylglutamic corrosive. The bioactive subsidiaries of acetamides are normally acquired from regular items and furthermore by manufactured strategies. Acetamide subsidiaries are the examination extent of lifted up percent likewise have a long history ${ }^{1}$. These mixes are artificially flexible atoms with a responsive carbonyl gathering. The level of 
reactivity of its carbonyl gathering towards nucleophilic reagents and this property has been broadly utilized in the writing, among the orchestrates by additionally an all the way open decent variety of heterocyclic mixes of restorative intrigue. They have extensive criticalness in their organic exercises and for their reactivity towards nucleophiles, which make free the combining of a likewise enormous expansion of heterocycles. Acetamide has atomic equation $\mathrm{C}_{2} \mathrm{H}_{5} \mathrm{NO}$.

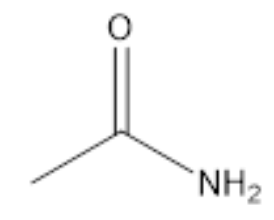

Figure 1: Acetamide

The acetamide subordinates and their analogs have an enormous variety of restorative properties including antiproliferative, mitigating, pain relieving, anticonvulsant, cell reinforcement, against angiogenic, anticancer, antifungal (phenyl-1-napthyl-phenyl acetamide and antibacterial and so on. A study on this writing on acetamide uncovers that these are intriguing focuses with regards to the union since such structures have potential for advancement of mixes for root development inhibitor, Developing new radiopharmaceuticals for symptomatic methods and treatment particularly on atomic medicament use radio-controlled tracers if toss gamma pillar from to inside body. Acetamide subordinates additionally discovered application in strong state science in the union of amino acids, normal mixes (alkaloids) and their homologs pharmacologically encouraging substances and biomarkers reagents for polymer change particle trade pitches for weighty and radioactive metal sorption. Chloro acetamide pesticides and colors are likewise notable. In this way, examination of acetamide science is a real assignment, both from hypothetical and applied perspectives $^{2-10}$.

The pharmacophore in existing medication particles once in a while applies a significant effect on the natural profile of the atoms. It has been seen that consolidation of certain bioactive. In light of these perceptions, it was foreseen that chloroacetylation of sulfonamide moiety and buildup with various subsidiaries of aniline and phenol could deliver intriguing arrangement of mixes which likely natural exercises $^{11-19}$.

As through writing study, it was discovered that acetamides bunches containing mixes show powerful skeletal muscle relaxant movement. So, we have likewise completed her skeletal muscle relaxant by the blended mixes by rota rod and actophotometer technique.

\section{Pharmacological Profile of Acetamide}

Ahmed et al. (2018) done the structure, blend, atomic docking of new lipophilic acetamide subsidiaries. The mixes were assessed for possible anticancer and antimicrobial action, managing likely anticancer and antimicrobial operator against Gram-positive and Gramnegative strains ${ }^{20}$.<smiles>NNS(=O)(=O)c1ccc(NC(=O)Cn2c(=O)c(-c3ccccc3)nc3ccccc32)cc1</smiles>

Figure 2.1

\begin{tabular}{|c|c|}
\hline Compound code & $\mathbf{R}$ \\
\hline 1 & $\mathrm{H}$ \\
\hline 2 & $\mathrm{COCH}_{3}$ \\
\hline 3 & 2-pyridinyl \\
\hline 4 & 2-Thiazoly \\
\hline 5 & $\mathrm{C}=(\mathrm{NH}) \mathrm{NH}_{2}$ \\
\hline 6 & 5-(3,4dimethyl) oxazolyl \\
\hline
\end{tabular}

Turan-Zitouni et al. (2018) carried out the synthesis of new thiazoline-tetralin Derivatives. The anticancer potency was evaluated on human breast adenocarcinoma cell line (MCF-7), human lung carcinoma cell line (A549) and mouse embryoblast cell line (NIH/3T3) using the MTT method, DNA synthesis inhibition and flow cytometric analysis ${ }^{21}$.<smiles>[R3]n1c(-c2ccccc2)cs/c1=N\NC(=O)COc1ccc2c(c1)CCCC2</smiles>

Figure 2.2

\begin{tabular}{|c|c|}
\hline Compound code & R1 \\
\hline 1 & $\mathrm{ClCH}_{2} \mathrm{COC}_{2} \mathrm{H}_{5} \mathrm{OH}$ \\
\hline 2 & $\mathrm{NH}_{2} \mathrm{NH}_{2} \cdot \mathrm{H}_{2} \mathrm{O}$ \\
\hline 3 & $\mathrm{C}_{6} \mathrm{H}_{5} \mathrm{NCS} \mathrm{C}_{6} \mathrm{H}_{11} \mathrm{NCS}$ \\
\hline 4 & Phenacyl bromide derivative \\
\hline
\end{tabular}

Janakiramudu et al. (2018) carried out a synthesis of sulfonamides and carbamates of 3-Fluoro-4-morpholino aniline (linezolid intermediate). The compounds were screened for the antimicrobial activity and molecular docking study ${ }^{22}$.<smiles>COC(=O)Nc1ccc(N2CCOCC2)c(F)c1</smiles>

Figure 2.3 
Khalid et al. (2018) carried out the Synthesis of 1, 2, 4 triazole hydration and sulfonamide novel derivatives. The compounds were screened for molecular docking evaluation of antiplatelet and anticoagulant actions ${ }^{23}$.

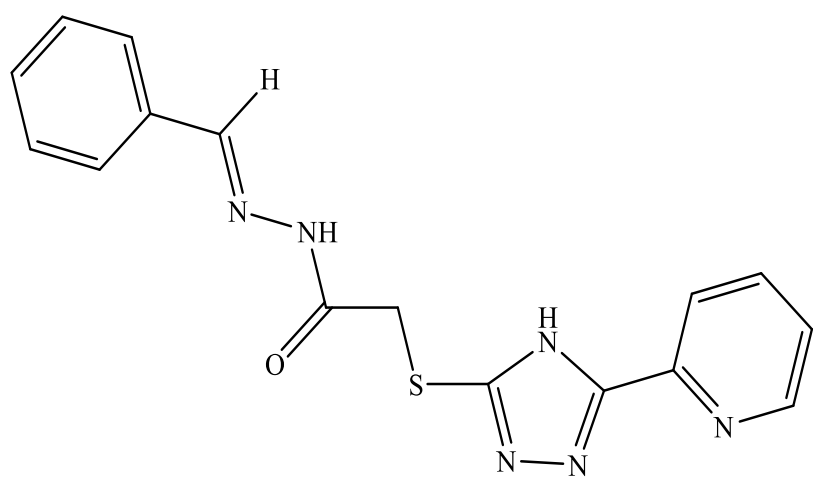

Figure 2.4

Lin $\mathrm{G}$ et al. (2018) carried out the synthesis of of $\mathrm{N}-\left(4-\left(\mathrm{N}\right.\right.$, , $^{-}$ substituted sulfamoyl) phenyl) myrtenamides containing a heterocycle. The compounds were exhibited antifungal activity against Physalospora piricola and Alternaria solani $i^{24}$.<smiles></smiles>

Figure 2.5

Alasmary et al. (2018) carried out the synthesis of novel acetamide derivatives. The compounds were synthesized, and evaluated for their anti-ulcerogenic \& Anti- Ulcerative colitis activities and showed curative activity against acetic acid induced ulcer model in a dose of $50 \mathrm{mg} / \mathrm{kg}^{25}$.<smiles>NS(=O)(=O)c1ccc(NC(=O)CNc2ccccc2C(=O)O)cc1</smiles>

Figure 2.6

Charaya et al. (2018) carried out the design and synthesis of novel thiazol-2-yl benzamide derivatives. A series of sisal-2-yl benzamide derivatives were synthesized from benzoic acid and evaluated by in vitro enzymatic assay for GK activation. In silico docking studies were carried out to determine the binding interactions for the best fit conformations in the allosteric site of GK enzyme ${ }^{26}$.<smiles>CNS(=O)(=O)c1cccc(C(=O)Nc2nc(C)cs2)c1</smiles>

Figure 2.7

Rutkauskas et al. (2017) carried out the synthesis of benzene sulfonamides bearing pyrrolidinone moiety. The compounds were evaluated for as inhibitors of carbonic anhydrase $\mathrm{IX}^{27}$.<smiles>NC(=S)NNC(=O)C1CC(=O)N(c2ccc(S(N)(=O)=O)cc2)C1</smiles><smiles>CCCCCNC(=O)C1CC(=O)N(c2ccc(S(N)(=O)=O)cc2)C1</smiles>

Figure 2.8

Bhuva et al. (2017) carried out the synthesis of pyrimidinyl sulfonamide derivatives. A small library of compounds is synthesized and evaluated for their in vitro antitubercular activity against Mycobacterium tuberculosis H37RV 28-29.<smiles>[R]c1nc(CC)nc(NS(=O)(=O)c2ccc(NC(C)=O)cc2)c1C(N)=O</smiles>

Figure 2.9

Hamas et al. (2017) carried out the synthesis of some new acetamide derivatives and 5-Benzylidene-2-(2,6-dimethylphenylimino) -thiazolidin-4-ones. The newly synthesized compounds were screened for their antimicrobial activities against two identifiable strains using cup, plate method, and most of the synthesized derivatives revealed discernible antibacterial activity ${ }^{30-31}$.<smiles>[R8]NCC(=O)Nc1c(C)cccc1C</smiles>

Figure $\mathbf{2 . 1 0}$ 
Maladies et al. (2017) Synthesis of 2,4-DI substituted furan derivatives. The synthesized compound screening for the antibacterial activity studied against Gram (+) and Gram () bacteria like antibacterial activity against Escherichia coli and Proteus vulgaris ${ }^{32-33}$.<smiles>O=C(N[Al])c1coc(CNCS(=O)(=O)c2ccccc2)c1</smiles>

Figure 2.11

Eswararao et al. (2017) carried out the synthesis of 2phenylindolizine acetamide derivatives. The compounds were screened for their antimicrobial activities of novel class of 2-phenylindolizin acetamide scaffolds are described by variation in the therapeutic effects of a parent molecule three medically relevant organisms like Staphylococcus aureus, Escherichia coli and Pseudomonas aeruginosa ${ }^{34-35}$.

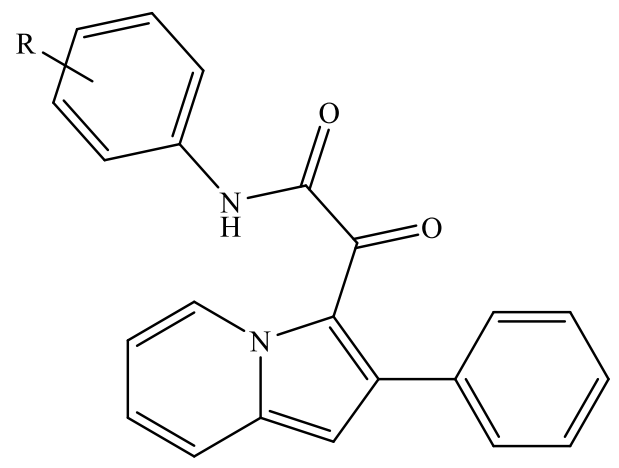

Figure 2.12

\begin{tabular}{|c|c|}
\hline Compound code & $\mathbf{R}$ \\
\hline 1 & $\mathrm{C}_{24} \mathrm{H}_{18} \mathrm{~N}_{2} \mathrm{O}$ \\
\hline 2 & $\mathrm{C}_{27} \mathrm{H}_{24} \mathrm{~N}_{2} \mathrm{O}_{4}$ \\
\hline 3 & $\mathrm{C}_{24} \mathrm{H}_{20} \mathrm{~N}_{2} \mathrm{O}_{4}$ \\
\hline 4 & $\mathrm{C}_{21} \mathrm{H}_{15} \mathrm{~N}_{3} \mathrm{O}_{2}$ \\
\hline 5 & $\mathrm{C}_{21} \mathrm{H}_{15} \mathrm{~N}_{3} \mathrm{O}_{2}$ \\
\hline 6 & $\mathrm{C}_{22} \mathrm{H}_{17} \mathrm{~N}_{3} \mathrm{O}$ \\
\hline 7 & $\mathrm{C}_{22} \mathrm{H}_{16} \mathrm{~N}_{2} \mathrm{O}_{4} \mathrm{~S}$ \\
\hline 8 & $\mathrm{C}_{25} \mathrm{H}_{22} \mathrm{~N}_{2} \mathrm{O}_{5}$ \\
\hline 9 & $\mathrm{C}_{23} \mathrm{H}_{17} \mathrm{~N}_{3} \mathrm{O}_{4}$ \\
\hline 10 & $\mathrm{C}_{25} \mathrm{H}_{20} \mathrm{~N}_{2} \mathrm{O}$ \\
\hline 11 & $\mathrm{C}_{21} \mathrm{H}_{15} \mathrm{~N}_{3} \mathrm{O}_{2}$ \\
\hline
\end{tabular}

Bach et al. (2017) carried out the synthesis of novel Nphenylacetamide bearing 1, 2, 4-triazole derivatives. The antimicrobial activities of the derivatives were measured against both bacteria and fungi ${ }^{36}$.<smiles>[R]c1cccc(NC(=O)Cn2cncn2)c1</smiles>

Figure 2.13

Nafeesa et al. (2017) carried out the synthesis of 1, 3, 4oxadiazole and acetamide derivatives of ethyl nipecotate. The synthesized compounds were evaluated for their antibacterial and anti-enzymatic potential supported by $\%$ hemolytic activity. The antibacterial screening against certain bacterial strains of gram negative and grampositive bacteria rendered compound as a good inhibitor of gram-negative bacterial strains ${ }^{37}$.

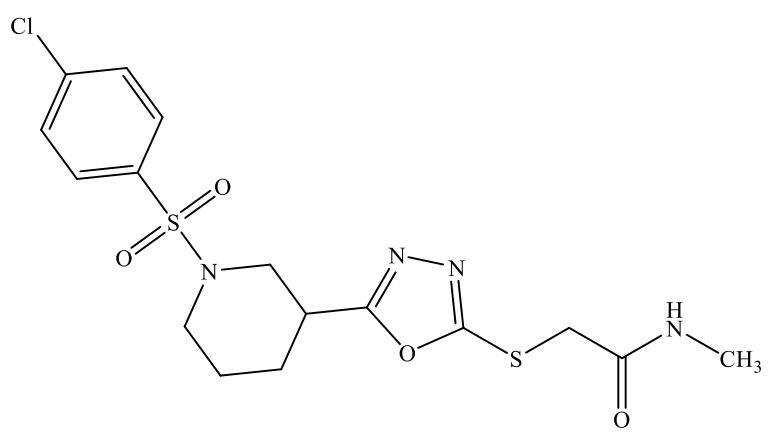

Figure 2.14

Yurttaş et al. (2017) carried out the synthesis of new 1, 3, 4-oxadiazole derivatives. The antimicrobial activity of the compounds was screened against seven Gram positive and Gram negative bacteria and four fungi species; Escherichia coli, Enterococcus faecalis, Enterococcus faecalis, Staphylococcus aureus, Klebsiella pneumoniae, Pseudomonas aeruginosa, Candida albicans, Candida krusei, Candida glabrata, Candida parapsilosis ${ }^{38}$.<smiles>Cc1ccc2nc(NC(=O)CSc3nnc(Cc4ccc(Cl)cc4)o3)sc2c1</smiles>

Figure 2.15

Verma et al. (2017) carried out the synthesis of one pot synthesis of 1,5-benzodiazepines and its chloroacetylated derivatives. The synthesized compounds and its physicochemical parameters were evaluated in order to determine the potency of the compounds for good CNS activity. This solvent free reaction mediated by glacial acetic acid was found to be very efficient with high yield ${ }^{39}$. 
<smiles>CC1=Nc2ccccc2N(C(=O)CCl)C(C)(C)C1</smiles>

Figure 2.16

Verma et al. (2017) Carried out the synthesis of A series of new N-(2-benzoyl-4-chlorophenyl) -2-(4-(substituted phenyl) piperazin-1-yl) acetamides. The compounds were screened for the anxiolytic and skeletal muscle relaxant activity in which computational studies with molecular docking revealed that the target compounds correctly dock into the binding pocket of the GABAA receptor ${ }^{39}$.

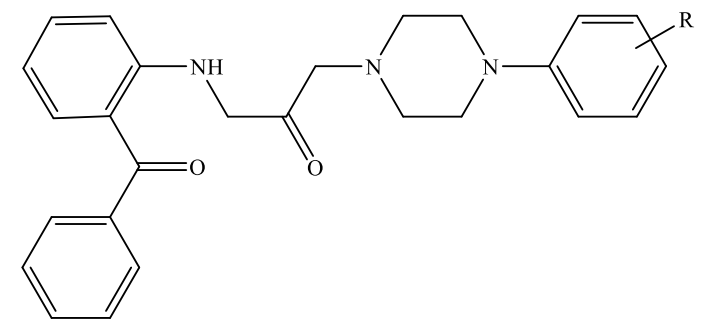

Figure 2.18

\begin{tabular}{|c|c|}
\hline Compound code & $\mathbf{R}$ \\
\hline 1 & $\mathrm{H}$ \\
\hline 2 & $\mathrm{COCH}_{3}$ \\
\hline 3 & $\mathrm{C}_{2} \mathrm{H}_{5}$ \\
\hline
\end{tabular}

Basra et al. (2016) carried out the synthesis of novel sulfonamides under mild conditions. The synthesized compounds were screened for effective inhibitory activity against the carbonic anhydrase isoforms I and II and the inhibition effects of on the hydrates and esterase activities of human carbonic anhydrase isoenzymes ${ }^{40}$.<smiles>[R]S(=O)(=O)Nc1ccc(C(=O)Nc2ccc(S(N)(=O)=O)cc2)cc1</smiles>

Figure 2.19

Kumar et al. (2017) carried out a series of Schiff bases of diphenylamine derivatives. The synthesized compounds were evaluated for the in-vitro for their antibacterial activity against pathogenic both Gram-positive bacteria $B$. subtilis and Gram-negative bacteria E. Coli, uses ciprofloxacin as standard drug ${ }^{41}$.<smiles>[R]C/C=N/c1ccccc1/C=N/c1ccc(OCC(=O)N(c2ccccc2)c2ccccc2)cc1</smiles>

Figure 2.20

Kumar et al. (2016) carried out a synthesis and computational studies of 2-[4-(aryl substituted) piperazine-1-yl] -N-benzylacetamides. The compounds were evaluated for potential antipsychotic activity by studying apomorphine induced climbing behavior, 5-HTP induced head twitches behavior and catalepsy in mice ${ }^{42}$.

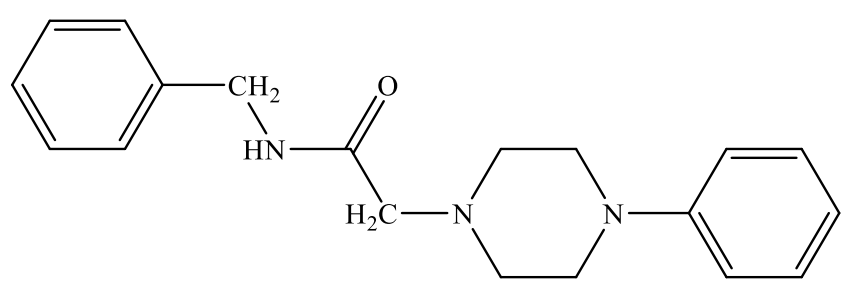

Figure 2.21

Cheng et al. (2016) carried out the discovery of Pyridinyl Acetamide Derivatives. Developed and performed a cellular high-throughput screen for inhibitors of Want secretion and pathway activation. A lead structure (GNF1331) was identified from the screen. Further studies identified the molecular target of GNF-1331 as Porcupine, a membrane bound $\mathrm{O}$-acyl transferase $\mathrm{H}^{43}$.<smiles>[X]c1ccc(NC(=O)Cc2ccc(-c3ccnc([R])c3)c([R2])c2)nc1</smiles>

Figure 2.22

Singh et al. (2015) carried out the synthesis of 2-amino-5chlorobenzophenone derivatives. All the synthesized compounds were subjected to physicochemical parameters determination for BBB penetration through online software. The experimentally determined and calculated values of log $P$ are very much similar to values of log $P$ calculated by the online software chemsilico and are in the range required for good CNS activity. The compounds were screened for the skeletal muscle relaxant activity and from the investigation ${ }^{44}$. 
<smiles>CCCCC(=O)Nc1ccc(Cl)cc1C(=O)c1ccccc1</smiles>

Figure 2.23

Rani et al. (2015) carried out the synthesis of substituted phenoxy acetamide derivatives. The compounds assessed for their anti-inflammatory activity by a carrageenan induced rat paw edema method, analgesic activity by Eddy's hot plate method and antipyretic activity of brewer's yeast induced pyrexia method ${ }^{45-46}$.<smiles>[R]c1cccc(OCC(=O)NC2CC3CCC2(C)C3(C)C)c1</smiles><smiles>[R]c1cccc(OCC(=O)NC2CCCCC2Br)c1</smiles>

Figure 2.24

Ugwu et al. (2014) carried out the synthesis of [4Methylphenylsulphonamido] -N-(Pyridin-2 YI) acetamide derivatives. The compounds were screened for antifungal activities against Candida albican and Aspergillus Niger. The results revealed that the compounds had better antifungal activity than fluconazole the reference drug ${ }^{47}$.<smiles>Cc1ccc(S(=O)(=O)NCC(=O)Nc2ccccn2)cc1</smiles>

Figure 2.25

Saudi et al. (2014) carried out the synthesis some novel sulfonamide and amide derivatives containing coumarin moieties. The compounds were screened for their antimicrobial and antioxidant activities. Their antimicrobial activity was assigned using the conventional agar dilution method and the antioxidant activity was assessed using two methods, 1,1-diphenyl-2-picrylhydrazyl (DPPH) radical scavenging method and ferric reducing antioxidant power (FRAP) assay ${ }^{48-50}$.<smiles>NS(=O)(=O)c1ccc(NC(=O)COc2ccc3c(c2)CCCC3)cc1</smiles>

Figure 2.26

Rathore et al. (2014) carried out the synthesis of some new pyrazoline substituted benzene sulfonylureas. The synthesized compound were screened for their antiproliferative activity towards 60 human cancer cell lines by the National Cancer Institute (USA) ${ }^{51}$.

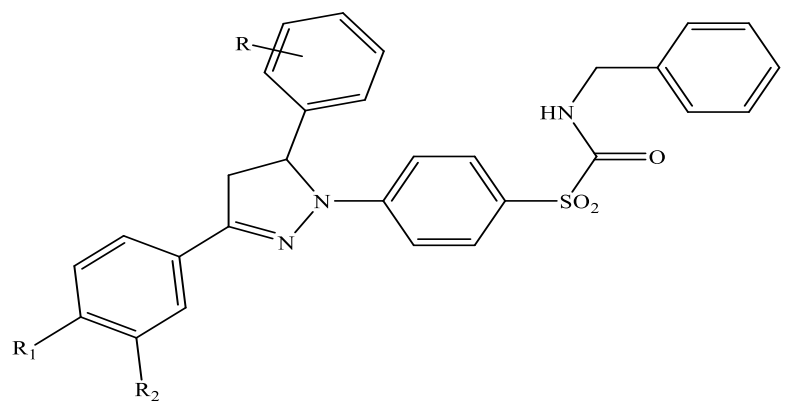

Figure 2.27

Pedgaonkar et al. (2014) carried out the development of 2-(4-oxoquinazolin-3 (4H) Yl) acetamide derivatives. The derivatives were synthesized and evaluated for their in vitro MTB InhA inhibition. Compounds were further evaluated for their in vitro activity against drug sensitive and resistant MTB strains and cytotoxicity against the RAW 264.7 cell line ${ }^{52}$.<smiles>O=C(Cn1cnc2ccc(Cl)cc2c1=O)Nc1cc(C(F)(F)F)ccc1Cl</smiles>

Figure 2.28

Koch et al. (2012) carried out the synthesis, of novel 1acetyl-3, 5-diaryl-4, 5-dihydro $(1 \mathrm{H})$ pyrazole derivatives bearing urea, thiourea and sulfonamide moieties. The compound have been screened for their pro-inflammatory cytokines (TNF-a and IL-6) and antimicrobial activity (antibacterial and antifungal) ${ }^{53-55}$. 


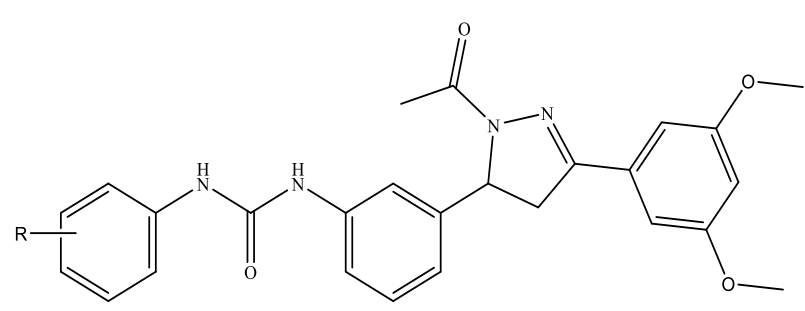

Figure 2.29

Fereyduni et al. (2012) carried out the synthesis of some n-phenylacetamide derivatives. For this purpose, density functional theory calculations were applied at the B3LYP/6-31 \pm G (d, p) level to calculate the aromaticity indices, including nucleus independent chemical shift (NICS), harmonic oscillator model of aromaticity (HOMA) and harmonic oscillator model of electron delocalization (HOMED). The obtained results indicated that the aromaticity of derivatives decreased in the order of NO2 > $\mathrm{CN}>\mathrm{CF} 3>\mathrm{Br}>\mathrm{Cl}>\mathrm{F}>\mathrm{H}>\mathrm{CH} 3>\mathrm{NH} 2$ for both Meta and para positions ${ }^{56}$.<smiles>[X]c1cccc(NC(C)=O)c1</smiles><smiles>[X]c1ccc(NC(C)=O)cc1</smiles>

Figure 2.30

\section{CONCLUSION}

From the above conversation, it tends to be inferred that the different strategies had been accounted for the arrangement of Phenytoin subordinates. The writing demonstrates that Acetamide show impacts like anticancer action, Anti-Inflammatory Activity, Antifungal Activities, Analgesic movement, CNS operator and so forth. From result and conversation we come to realize that the replacements on sweet-smelling amine have incredible hugeness to yield a worth. The rate yield is expanded by the replacement at para and Meta position of the ring, though it diminishes on account of other replacement because of strike viably. The means included buildup followed by $\mathrm{N}$ Acylation, Vilsmeier-Haack response or Thermal cycloaddition. This article gives different techniques to plan more subordinates of acetamide to investigate more exercises of acetamide.

Acknowledgments: I need to recognize my appreciation to MET, Faculty of Pharmacy for giving me library offices to develop my insight and to urge me to compose this article.

I am extremely grateful to my educator Ms. Pooja Saini, for giving me the necessary data and for their enterprise.

\section{REFERENCES}

1. Horton DA, Bourne GT. and Smythe ML, The combinatorial synthesis of bicyclic privileged structures or privileged substructures. Chemical Reviews. 103, 2003, 893-930 Doi.org/10.1021/cr020033s

2. Kasai S, Nagasawa H, Yamashita M, Masui M, Kuwasaka H, Oshodani T, Uto Y, Inomata T, Oka S, Inayama S, Hori H. New antimetastatic hypoxic cell radiosensitizers: design, synthesis, and biological activities of 2-nitroimidazole-acetamide, TX-1877, and its analogues. Bio. Org. Med. Chem. 9, 2001, 453-64.

DOI: 10.1016/s0968-0896(00)00265-0 PMID: 11249137

3. Kumar AR, Murugesan SK, Synthesis and characterization of some novel azetidinone derivative as antibacterial and anticonvulsant agents. J. Pharma. Bio. Resources. 2, 2005, 162-168. DOI:10.4314/JPB.V212.32080

4. Steffi N, Marifeat K, Lidija S, Holger S, Ivo P. Synthesis of modified pyrimidine base and positive impact of chemically reactive substituted on their in vitro antiproliferative activity. Eup. J. Med. Chem. 44, 2009, 1172-1179. Doi: 10.1016/j.ejmech.2008.06.002

5. Wang K, Shen HH, Chen JC, Chen Z. Inhibitory effect of acetamide-45 on airway inflammation and phosphodiesterase 4 in allergic rats. Acta Parma. Sinica. 26,2005, 1492-6.

Doi: 10.1111/j.1745-7254.2005.00227.x.

6. Zafer AK, Mehlika DA, Gulhan TZ. Ahmet O, Ozgur DC. Synthesis and analgesic activity of some acetamide derivatives. J. Enzyme Inhibition and Medicinal Chem. 36, 2008, 2419-2430.

7. Lee J, Shim JS, Jung SA, Lee ST, Kwon HJ. N-Hydroxy-2- (naphthalene2-ylsulfanyl)-acetamide, a novel hydroxamic acid-based inhibitor of aminopeptidase $\mathrm{N}$ and its anti-angiogenic activity. Bio. Med. Chem. $15,2004$.

doi.org/10.1016/j.bmcl.2004.10.010

8. Dhanasekaran, D, Thajuddin N, Panneerselvam A. An antifungal compound: 4-phenyl-1-napthayl - Phenyl acetamide from streptomyces SP. Medicine and Biology, 15: 1, 2008, 7-12.

9. Mostafa MG, Fatma AR, Helmy $H$, Hebaallah MA, Synthesis of some novel sulfonamides containing biologically active alkanoic acid, acetamide, thiazole, and pyrrole moieties of expected antitumor and radiosensietizing activities. J. Basic. Appl. Chem. 2, 2011, 8-14.

10. Zaragoza $F$, Stephensen $H$, Solid-phase synthesis of substituted 4acyl1, 2, 3, 4-tetrahydroquinoxalin-2-ones. J. Org. Chem. 64, 1999, 2555.

Doi.org/10.1021/jo982070i

11. Sirasani G, Andrade RB, Sequential One-Pot Cyclizations: Concise Access to the ABCE Tetracyclic Framework of Strychnos Alkaloids Organic. Org. Lett. 11, 2009, 2085.

\section{DOI: 10.1021/ol9004799 PMID: 19382776}

12. Taylor JA, Pasha K, Phillips DAS. The dyeing of cotton with hetero bifunctional reactive dyes containing both a monochlorotriazinyl and a chloroacetylamino reactive group, Dyes and Pigments. 51, 2001, 145. Doi.org/10.1016/S0143-7208 (01)00065-1

13. Teramoto $\mathrm{K}$, Chemical modification of polystyrene surfaces by amidomethylation reaction with $\mathrm{N}$-methylol-2-chloroacetamide. Reactive Polymers. 15, 1991, 89. 
Doi.org/10.1016/0923-1137 (91)90152-E

14. Shaul M, Abourbeh G, Jacobson O, Rozen Y, Laky D, Levitzki A, Mishani E, Novel iodine-124 labeled EGFR inhibitors as potential PET agents for molecular imaging in cancer, Bio. Org. Med. Chem. 12, $2004,3421$.

\section{DOI: 10.1016/j.bmc.2004.04.044 PMID: 15186828}

15. Neagu V. Removal of $\mathrm{Cr}(\mathrm{VI})$ onto functionalized pyridine copolymer with amide groups, J. Hazardous Materials. 2009, 171: 410. 31. Schmalfu, J., Matthes, B., Knuth, K. and Boger, P., Inhibition of AcylCoA elongation by chloroacetamide herbicides in microsomes from leek seedlings, Pesticide Biochemistry and Physiology. 67, 2000, 25.

DOI: 10.1016/j.jhazmat.2009.06.016 PMID: 19647364

16. Okuro KSY, Suzuki I, Mitsuda MP. Novel Chiral Template for the Preparation of $\alpha$-Amino Acids: Practical Synthesis and Application, Chem. Inform. 41, 2010, 89.

DOI: 10.1021/bk-2009-1009.ch006.

17. Bilgiç $S$, Bilgiç $O$, Bilgiç $M O$, Gunduz $M$, Karakoç $N$, Synthesis of 2-aryl1,2-dihydronaphtho[1,2-f][1,4]oxazepin-3(4H)-ones Part I , ARKIVOC. 2009, 13: 185-192.

18. Kaoudi T, Miranda LD, Zard SZ. An easy entry into berbane and alloyohimbane alkaloids via a 6- exo radical cyclization, Org. Lett. 3, 2001, 3125.

Doi.org/10.1021/ol016424v.

19. Ahmed HEA, Ihmaid SK, Omar AM, Shehata AM, Rateb HS, Zayed MF, Ahmed S, Elaasser MM. Design, synthesis, molecular docking of new lipophilic acetamide derivatives affording potential anticancer and antimicrobial agents. Bioorganic Chemistry 76, 2018, 332-342.

DOI: 10.1016/j.bioorg.2017.11.019 PMID: 29227917.

20. Turan-Zitouni Gülhan, Yurtta Leyla, Tabbi Aouatef, Çiftçi GA, Temel HE, Kaplancıklı ZA. New Thiazoline-Tetralin Derivatives and Biological Activity Evaluation. Molecules 23, 2018, 135.

Doi.org/10.3390/molecules23010135

21. Jadagoudar YP, Upase DS, Patil AP, Koti BC, Ronad PM. Neuropharmacological Profile of Some Novel Coumarin Derivatives in Mice. International Journal of Pharmaceutical Research and BioScience. 3(4), 2014, 216-242.

22. Lin G, Duan W, Liu H, Ma Y, Lei F. Synthesis and bioactivity of n-(4-(n'substituted sulfamoyl) phenyl)myrtenamides containing a heterocycle. Chemistry of Natural Compounds 54(1), 2018, 56-62.

Doi.10.1007/8 10600-018-2258-6.

23. Abu-Khadra AS, Afify AS, Mohamed A, Farag RS, Aboul-Enein HY. Preparation, Characterization and Antimicrobial Activity of Schiff Base of (E) - N - (4-(Thiophen-2-ylmethyleneamino) Phenylsulfonyl) Acetamide Metal Complexes. The Open Bioactive Compounds Journal 6, 2018, 1-10.

\section{DOI: $10.2174 / 1874847301806010001$}

24. Alasmary FAS, Awaad AS, Alafeefy AM, El-Meligy RM, Alqasoumi SI. Novel quinazoline and acetamide derivatives as safe anti-allergenic agent and anti-ulcerative colitis activity. Saudi Pharmaceutical Journal 26, 2018, 138-143.

Doi: 10.1016/j.jsps.2017.09.011, PMID: 29379346.

25. Charaya N, Pandita D, Grewal AS, Lather V. Design, synthesis and biological evaluation of novel thiazol-2-yl benzamide derivatives as glucokinase activators. Computational Biology and Chemistry 73, 2018, 221-229.

Doi.org/10.1016/j.compbiolchem.2018.02.018

26. Rutkauskas K, Zubrienè A, Tumosienè I, Kantminienė K, Mickevičius $\mathrm{V}$, Matulis $\mathrm{D}$. Benzenesulfonamides bearing pyrrolidinone moiety as inhibitors of carbonic anhydrase IX: synthesis and binding studies. Medicinal Chemistry Research 26 (1), 2017, 235-246.

\section{DOI 10.1007/s00044-016-1741-5}

27. Bhuva NH, Talpara PK, Singala PM, Gothaliya VK, Shah VH. Synthesis and biological evaluation of pyrimidinyl sulfonamide derivatives as promising class of antitubercular agents. Journal of Saudi Chemical Society, 21, 2017, 517-527.

Doi.org/10.1016/j.jscs.2015.05.007

28. Bochao L, Xinrui L, Yumin Z, Dawei Z, Yang X, Feng L. Synthesis and Characterization of Novel N-Phenylacetamide Bearing 1,2,4-Triazole Derivatives as Potential Antimicrobial Agents. Chem. Res. Chin. Univ. 33(1), 2017, 70-73.

Doi: $10.1007 / s 40242-017-6327-3$

29. Hess FD, Deal M. An Analysis of the Growth Inhibitory Characteristics of Alachlor and Metolachlor, Weed Science. 28, 1980, 168-175.

30. H. Z. Shams, R. M. Mohareb, M. H. Helal, S. Mahmoud Ael Novel synthesis and antitumor evaluation of polyfunctionally substituted heterocyclic compound derived from 2-cyano-N-(3-cyano-4,5,6,7tetrahydrobenzo [b] thiophen-2-yl)-acetamide. Molecules, 26, 2011, 6271 DOI: 10.3390/molecules16010052, PMID: 21187817

31. Malladi S, Nadh RV, Babu KS, Babu PS. Synthesis and antibacterial activity studies of 2,4-di substituted furan derivatives. Beni-Suef University Journal of Basic and Applied Sciences 6, 2017, 345-353. Doi.org/10.1016/j.bjbas.2017.08.001

32. M. A. Sridhar, A. M. Babu, A. Indira,S. B. Bellad, J. Shashidhara Prasad, P. G. Ramappa, G. Nagendrappa. Crystal structure of lignocaine tetrachlorocuprate, Zeitschrift Fur Kristallographie, 202, 1992 , 3-4. : Doi.org/10.1524/zkri.1992.202.3-4.292

33. Eswararao SV, Venkataramireddy V, Sreenivasareddy M, Pramod K. Synthesis, Biological Activity of 2-phenylindolizine Acetamide Derivatives as Potential Antibacterial Agents. Der Pharma Chemicals 9 (18), 2017, 21-28.

34. Evans MJ, Cravatt BF. Mechanism-based profiling of enzyme families Chem. Rev. 2006, 106: 3279. (b) Cutri S., Diez A., Bonin M., Micron, L. And Husson H., Synthesis of novel polycyclic indolyldiamines, Org. Let. 7, 2005, 1911. doi.org/10.1021/ol047408b

35. Beale JM, Block JH, Wilson and Giswold's Text Book of Medicinal and Pharmaceutical chemistry. 12th edition, Lippincott Williams and Wilkin publication $2011,1-2$.

36. Nafeesa K, Rehman A-u, Abbasi MA, Siddiqui SZ, Rasool S, Shah SAA. Synthesis, characterization and pharmacological evaluation of different 1,3,4-oxadiazole and acetamide derivatives of ethyl nipecotate. Bulletin of Faculty of Pharmacy, Cairo University 55, 2017, 333-343. Doi.org/10.1016/j.bfopcu.2017.06.001

37. Yurttaş L, Bülbül EF, Tekinkoca S, Demirayak Ş. Antimicrobial Activity Evaluation Of New 1,3,4-oxadiazole Derivatives. Acta Pharmaceutica Sciencia 55(2), 2017, 45-54. DOI: 10.23893/1307-2080.APS.05511

38. Verma S, Kumar S, Kumar S. Synthesis, Computational and Pharmacological Evaluation of N-(2-benzoyl- 4-chlorophenyl)-2-(4(Substituted Phenyl) Piperazin-1-yl) Acetamides as CNS Agents. 
Central Nervous System Agents in Medicinal Chemistry 17(3), 2017, 229-238. Doi: 10.2174/1871524917666170321103951, PMID: 28325152.

39. Basar E, Tunca E, Bulbul M, Kaya M. Synthesis of novel sulfonamides under mild conditions with effective inhibitory activity against the carbonic anhydrase isoforms I and II. Journal of Enzyme Inhibition and Medicinal Chemistry, 31 (6), 2016, 1356-1361. Doi: org/10.3109/14756366.2015.1134524.

40. Kumar A, Verma S, Mishra AK, Kumar S. Synthesis of some new Schiff bases of Pharmaceutical Interest. Annals of Advances in Chemistry 1, 2017, 053-056. DOI: 10.29328/journal.aac.1001006

41. Singh RK, Devi Sonia, Prasad DN. Synthesis, physicochemical and biological evaluation of 2-amino-5-chlorobenzophenone derivatives as potent skeletal muscle relaxants. Arabian Journal of Chemistry 8 , 2015, 307-312. Doi. Org/10.1016/j.arabjc. 2011.11.013.

42. Cheng D, Liu J, Han D, Zhang G, Gao W, Hsieh MH, Ng N, Kasibhatla S, Tompkins C, Li J, Steffy A, Sun F, Li C, Seidel HM, Harris JL, Pan S. Discovery of Pyridinyl Acetamide Derivatives as Potent, Selective, and Orally Bioavailable Porcupine Inhibitors. ACS Medicinal Chemistry Letters 7(7), 2016, 676-680. doi.org/10.1021/acsmedchemlett.6b00038

43. Altıntop MD, Ciftci HI, Radwan MO, Sever B, Kaplancıklı ZA, Ali TFS, Koga R, Fujita M, Otsuka M, Özdemir A. Design, Synthesis, and Biological Evaluation of Novel 1,3,4-Thiadiazole Derivatives as Potential Antitumor Agents against Chronic Myelogenous Leukemia: Striking Effect of Nitrothiazole Moiety. Molecules 23 (59), 2018; 1-17. Doi: 10.3390/molecules23010059.

44. Rani P, Pal DK, Hegde RR, Hashim SR. Synthesis, characterization and pharmacological evaluation of substituted phenoxy acetamide derivatives. Hem. ind. 69(4), 2015, 405-415. DOI: 10.2298/HEMIND140330057R.

45. Autore G, Caruso A, Marzocco S, Nicolaus B, Palladino C, Pinto A, Popolo A, Sinicropi MS, Tommonaro Giuseppina, Saturnino Carmela. Acetamide Derivatives with Antioxidant Activity and Potential AntiInflammatory Activity. Molecules 15, 2010, 2028-2038.

46. Ugwu DI, Okoro UC. Synthesis, Characterisation and Antifungal Activities of [4-Methylphenylsulphonamido]-N-(Pyridin-2 YI) Acetamide Derivatives. Medicinal chemistry 4(2), 2014, 330-333. DOI: 10.4172/2161-0444.1000160.

47. Saeedia M, Golia F, Mahdavia M, Dehghanb G, Faramarzic MA, Foroumadia A, Shafiee A. Synthesis and Biological Investigation of some Novel Sulfonamide and Amide Derivatives Containing Coumarin Moieties. Iranian Journal of Pharmaceutical Research 13(3), 2014, 881-892. PMCID: PMC4177648.

48. S. Deniz, Dogruer, E. Kupeli, Erdem, M. Yesilada, S. Fethi. Archiv. Synthesis of New 2-[1(2H)-Phthalazinon-2-yl]acetamide and 3[1(2H)-Phthalazinon-2-yl]propanamide Derivatives as Antinociceptive and Anti-inflammatory Agents der Pharmazie, 337, 2004, ,303. Doi.org/10.1002/ardp.200200719.

49. Saravanan C, Punitha AD, Srivastava AK, Nath G, Singh SK. Antibacterial activity of novel 2-(substituted sulfonamido) benzoic acid derivatives. Journal of Pharmacy Research, 7, 2013, 525-528. DOI: 10.1016/j.jopr.2013.06.011.

50. Rathore $P$, Yaseen $S$, Ovais $S$, Bashir R, Yaseen R, Hameed AD, Samim $M$, Gupta R, Hussain F, Javed K. Synthesis and evaluation of some new pyrazoline substituted benzenesulfonylureas as potential antiproliferative agents. Bioorganic \& Medicinal Chemistry Letters 24, 2014, 1685-1691. DOI: 10.1016/j.bmcl.2014.02.059

51. Pedgaonkar GS, Sridevi JP, Jeankumar VU, Saxena S, Devi PB, Renuka J, Yogeeswari P, Sriram D. Development of 2-(4-oxoquinazolin-3(4H)$\mathrm{yl})$ acetamide derivatives as novel enoyl-acyl carrier protein reductase (InhA) inhibitors for the treatment of tuberculosis. European Journal of Medicinal Chemistry, 86, 2014, 613-627. Doi.org/10.1016/j.ejmech.2014.09.028

52. Keche AP, Hatnapure GD, Tale RH, Rodge AH, Kamble VM. Synthesis, anti-inflammatory and antimicrobial evaluation of novel 1-acetyl-3,5diaryl-4,5-dihydro $(1 \mathrm{H})$ pyrazole derivatives bearing urea, thiourea and sulfonamide moieties. Bioorganic \& Medicinal Chemistry Letters 22, 2012, 6611-6615. Doi: 10.1016/j.bmcl.2012.08.118.

53. Kyle C. A handbook for the interpretation of laboratory tests. 4th Ed. Auckland: Diagnostic Medlab 2008.

54. El-Sayed MT, El-Sharief MAMS, Zarie ES, Morsy NM, Elsheakh AR, Voronkov Andrey, Berishvili V, Hassan GS. Design, synthesis, antiinflammatory activity and molecular docking of potential novel antipyrine and pyrazolone analogs as cyclooxygenase enzyme (COX) inhibitors. Bioorganic \& Medicinal Chemistry Letters 28, 2018, 952957. Doi.org/10.1016/j.bmcl.2018.01.043.

55. Fereyduni E, Kamaee M, Soleymani R, Ahmadi R. The substitution effect on the aromaticity of some $n$-phenylacetamide derivatives: a DFT study. Journal of Theoretical and Computational Chemistry 11 (6), 2012, 1331-1339. Doi.org/10.1142/S0219633612500903.

\section{Source of Support: None declared.}

Conflict of Interest: None declared.

For any question relates to this article, please reach us at: editor@globalresearchonline.net New manuscripts for publication can be submitted at: submit@globalresearchonline.net and submit_ijpsrr@rediffmail.com 